\title{
Can preterm birth affect the palate morphology? A systematic review
}

\author{
O nascimento prematuro pode afetar a morfologia do palato? Uma revisão sistemática \\ ¿Puede el parto prematuro afectar la morfología del paladar? Una revisión sistemática
}

Received: 07/28/2021 | Reviewed: 07/31/2021 | Accept: 07/31/2021 | Published: 08/06/2021

Layza Rossatto Oppitz

ORCID: https://orcid.org/0000-0003-2672-646X Pontifícia Universidade Católica do Paraná, Brazil

E-mail: layza.oppitz@yahoo.com.br

Flavio Magno Gonçalves

ORCID: https://orcid.org/0000-0002-7972-2844

Tuiuti University of Paraná, Brazil

E-mail: flaviomagno93@yahoo.com.br

Neblyssa Agatha Schneider

ORCID: https://orcid.org/0000-0003-2631-1678

Pontifícia Universidade Católica do Paraná, Brazil

E-mail: neblyssa@gmail.com

Ana Carolina Mastriani Arantes

ORCID: https://orcid.org/0000-0001-6787-1415

Pontifícia Universidade Católica do Paraná, Brazil E-mail: ana_mastriani@hotmail.com

Bruna Marlene de Miranda

ORCID: https://orcid.org/0000-0002-3794-1221

Tuiuti University of Paraná, Brazil

E-mail: brunamiranda98@hotmail.com

Odilon Guariza-Filho

ORCID: https://orcid.org/0000-0001-9799-1223

Pontifícia Universidade Católica do Paraná, Brazil

E-mail: odilongfilho@gmail.com

Aline Cristina Batista Rodrigues Johann

ORCID: https://orcid.org/0000-0002-1678-9363

Pontifícia Universidade Católica do Paraná, Brazil

E-mail: alinecristinabatista@yahoo.com.br

Cristiano Miranda de Araujo

ORCID: https://orcid.org/0000-0003-1325-4248

Tuiuti University of Paraná, Brazil

E-mail: cristiano.araujo@utp.br

Elisa Souza Camargo

ORCID: https://orcid.org/0000-0002-7382-1526

Pontifícia Universidade Católica do Paraná, Brazil

E-mail: escamargo@uol.com.br

\begin{abstract}
The purpose of this review was to evaluate whether preterm birth affects palate morphology. Opened electronic search in PubMed (MEDLINE), Lilacs, Scopus and Web of Science was conducted and a partial search of the gray literature using Google Scholar, Open Gray and ProQuest. We included studies with infants born prematurely (born up to the 37th week of gestation and weighing less than $2.500 \mathrm{~g}$ ) and not preterm infants; intubated and not intubated. Two independent reviewers performed study selection, data extraction, and bias risk assessment. Selection criteria included observational, retrospective and prospective, randomized or nonrandomized cohort studies and control studies. There was no restriction on publication time and article language. A total of 2344 articles were found after the duplicates were removed, of which 7 met the inclusion criteria and were submitted to a Bias Risk analysis using MASTARI. Scientific evidence was found for altered palate morphology among premature infants, and oral intubation was a contributing factor for such alterations. Based on this review, it is concluded that premature birth changes palate morphology, when prematurity is associated with the use of the orotracheal tube.
\end{abstract}

Keywords: Palate; Premature newborn; Systematic review.

\section{Resumo}

O objetivo desta revisão foi avaliar se o nascimento prematuro afeta a morfologia do palato. Foi realizada uma busca eletrônica no PubMed/Medline, Lilacs, Scopus e Web of Science e uma busca parcial da literatura cinzenta usando Google Scholar, Open Grey e ProQuest. Foram incluídos estudos com bebês nascidos prematuramente (nascidos até a 
$37^{\mathrm{a}}$ semana de gestação e com peso inferior a $2.500 \mathrm{~g}$ ) e não prematuros; entubados e não intubados. Dois revisores independentes realizaram a seleção do estudo, extração de dados e avaliação de risco de viés. Os critérios de seleção incluíram estudos observacionais, retrospectivos e prospectivos, randomizados ou não randomizados de coorte e estudos de controle. Não houve restrição quanto ao tempo de publicação e idioma do artigo. Após a retirada das duplicatas, foram encontrados 2.344 artigos, dos quais 7 atenderam aos critérios de inclusão e foram submetidos à análise de risco de viés pela ferramenta MASTARI. Evidências científicas foram encontradas para alteração da morfologia do palato em prematuros, e a intubação oral foi um fator contribuinte para tais alterações. Com base nesta revisão, conclui-se que o nascimento prematuro altera a morfologia do palato, quando a prematuridade é associada ao uso da sonda orotraqueal.

Palavras-chave: Palato; Nascimento prematuro; Revisão sistemática.

\section{Resumen}

El objetivo de esta revisión fue evaluar si el parto prematuro afecta la morfología del paladar. Se realizó una búsqueda electrónica en PubMed / Medline, Lilacs, Scopus y Web of Science y una búsqueda parcial de literatura gris utilizando Google Scholar, Open Grey y ProQuest. Se incluyeron estudios con bebés nacidos prematuramente (nacidos hasta la semana 37 de gestación y con un peso inferior a 2500 g) y no prematuros; intubados y no intubados. Dos revisores independientes realizaron la selección de estudios, la extracción de datos y la evaluación del riesgo de sesgo. Los criterios de selección incluyeron estudios observacionales, retrospectivos y prospectivos, estudios de control y de cohortes aleatorizados o no aleatorizados. No hubo restricciones sobre el tiempo de publicación y el idioma del artículo. Tras retirar los duplicados, se encontraron 2.344 artículos, de los cuales 7 cumplieron con los criterios de inclusión y fueron sometidos a análisis de riesgo de sesgo mediante la herramienta MASTARI. Se encontró evidencia científica de cambios en la morfología del paladar en bebés prematuros, y la intubación oral fue un factor que contribuyó a tales cambios. Con base en esta revisión, se concluye que el parto prematuro altera la morfología del paladar, cuando la prematuridad se asocia con el uso de sonda orotraqueal.

Palabras clave: Paladar; Parto prematuro; Revisión sistemática.

\section{Introduction}

According to the World Health Organization (WHO) definition, premature birth is one that occurs before 37 weeks of gestation, or where the birth weight is less than $2.500 \mathrm{~g}$. The incidence of preterm birth varies widely among different populations and is generally correlated with differences in living conditions between developing and developed countries (Avery 1988). Brazil is among the 10 countries with the highest rates and is responsible for $60 \%$ of premature births in the world.(World Health Organization 2015).

The short-term and long-term effects of preterm birth on a child's physical and psychological growth and development have been a topic of interest. Some studies have indicated that infants with low birth weight present significant delays in many areas of growth and physical and psychological development(Marlow, Roberts et al. 1993, Wolke 1998). Low birth weight children, especially those with more severe conditions, tend to be lower and with a cephalic perimeter smaller than the total (Stjernqvist and Svenningsen 1999, Stankiewicz, Palko et al. 2017).

The brain, lungs, and eyes are the most susceptible organs (Lissauer T 1997), but facial bones and palate morphology may also be affected, and this prevalence ranges from 0 to 10\% in premature children(Kopra and Davis 1991), and 10 to 70\% in children low birth weight or very low birth weight (Kopra and Davis 1991, Hohoff, Rabe et al. 2005). Studies have shown that the palate of premature infants has the narrowest and deepest form when compared to the palate of non-premature infants (Kopra and Davis 1991, Macey-Dare, Moles et al. 1999). Due to this , there is a greater risk of future establishment of malocclusion, difficulties in chewing or speaking and aesthetic problems (Paulsson, Bondemark et al. 2004, Hohoff, Rabe et al. 2005, Magalhaes, Pereira et al. 2010). Thus, for these patients, orthodontic treatment will be indicated to correct dental malocclusion and possibly redirect skeletal growth (Paulsson, Soderfeldt et al. 2008).

Morphological changes in the palate may occur due to oro- or nasotracheal tube pressure, or direct trauma from the laryngoscope when the tube is placed (Seow 1997) and duration of intubation is a determining factor for the severity of these changes (Fadavi, Adeni et al. 1992). However, it is not clear whether these alterations occur only because of preterm birth, or if there is any correlation with other factors, given the different definitions of prematurity (weight at birth or gestational age) and 
confounding factors, such as intubation, in the literature.

In the systematic review by Paulsson et al. (Paulsson, Bondemark et al. 2004), scientific evidence was found for the change in short-term palatine morphology among premature infants, and oral intubation was a contributing factor for the changes. However, these authors concluded that the results found were contradictory, there were no longitudinal studies and, therefore, the scientific evidence was too weak to answer if premature birth causes such intra-oral changes. Several articles on this topic were published in the literature, so a new systematic review is justified to answer this important question.

Thus the purpose of this systematic review was to verify if the premature birth alters the palatal morphology.

\section{Methodology}

\subsection{Study design}

This systematic review was performed according to the Guideline PRISMA (Preferred Reporting Items for Systematic Reviews and Meta-Analysis Checklist) (Moher, Liberati et al. 2009). Its protocol was recorded on the PROSPERO (International Prospective Register of Systematic Review), number CRD42017078441.

\subsection{Study sources}

A systematic search was conducted in the PubMed (MEDLINE), Lilacs, Scopus and Web of Science electronic databases. The grey literature was searched in the OpenGrey, ProQuest and Google Scholar database. There was no restriction on the language and the date of publication for study selection. The last search was carried out on December 2018.

\subsection{Search strategy}

Thus the purpose of this systematic review was to answer the PECOS question: "Does preterm birth alter the morphology of the palate?" (Participants: Newborns; Exposure: Premature birth; Comparison / Control: Non-premature births; Outcome / Outcomes: Palate morphology (primary outcome) and Intubation (secondary outcome); Types of Included Studies: Observational, cohort prospective or retrospective, randomized or non-randomized studies, case-control studies). The following terms have been adapted for each electronic database:

('premature birth OR "Very pretem infant" OR "Premature Births" OR "Preterm Birth" OR "Preterm Births" OR "Premature Infant" OR "low- birthweight infants" OR "low birth weight" OR "Low-birth weight" OR "Very low birth weight" OR "Very preterm birth" OR "Preterm Infants" OR "Preterm Infant" OR "Premature Infants" OR "Neonatal Prematurity") AND ("palate" OR "palatal" OR "palatal morphology" OR "Palatine Bone" OR "palate, hard" OR "Hard Palates" OR "Hard Palate").

\subsection{Inclusion criteria}

We included studies with a sample composed of babies born preterm, that is, with birth before the 37th week, or those whose birth weight was less than $2.500 \mathrm{~g}$ and studies in which the morphology of the palate in premature babies was evaluated. There was no restriction on publication time and article language.

\subsection{Exclusion criteria}

Articles with infants not born prematurely or weighing more than $2.500 \mathrm{~g}$, presence of growth and / or genetic disorders or syndromes, animal studies, studies that did not evaluate palate morphology, studies using palatine devices, reviews, letters, conference summaries, expert opinions, case reports, and narrative review articles. 


\subsection{Selection process}

The selection of articles in two phases was carried out. In the first phase, two authors (L.R.O. and N.S.S.) independently reviewed the titles and abstracts of all references. All articles that did not meet the inclusion criteria were excluded. In phase 2, the same authors independently read the selected articles.

Disagreements were resolved through discussions, and when there was no mutual agreement between the first two authors, a third author (C.M.A.) was involved for the final decision. In addition, all duplicate references and references without duplicate were managed using the reference manager software (EndNote $\mathrm{x} 7$ ).

\subsection{Data collection}

Two authors (L.R.O. and N.S.S.) collected the information from the included studies, and this information was discussed. The data collected consisted of: characteristics of the study (authors, year of publication, country, study design), population characteristics (sample size, age), evaluation characteristics (outcome evaluation method), results relation to palate morphology, statistical data) and main conclusions.

\subsection{Risk of bias assessment}

The methodology of the selected studies was evaluated using the bias risk tool Meta Analysis of Statistics Assessment and Review Instrument (MASTARI). The risk of bias was categorized as "high" when the study presented a "yes" score greater than 49\%; "Moderate" when the study presented between 50\% and 69\% of the "yes" score; and "low" when the study presented more than $70 \%$ "yes" score for the bias risk questioning.

\section{Results}

\subsection{Selection of studies}

In phase 1, 2.663 articles were identified in the 4 databases chosen. After the removal of duplicate articles, 2.344 articles remained. Phase 1 resulted in the exclusion of 2.337 articles, with 27 articles remaining to be qualified in phase 2 . In phase 2, 20 were excluded that did not meet the inclusion criteria.

In addition, articles in the gray literature (Google Scholar, Proquest, and OpenGrey) were reviewed and references of the articles included in Phase 2 were reviewed to assess whether any additional articles could be included. No articles have been added because they do not meet the inclusion criteria. The search strategy resulted in 7 articles at the end of phase 2 . The flowchart with the number of references retrieved in each phase is available in Figure 1. 
Figure 1 - Flowchart of literature search and selection criteria.

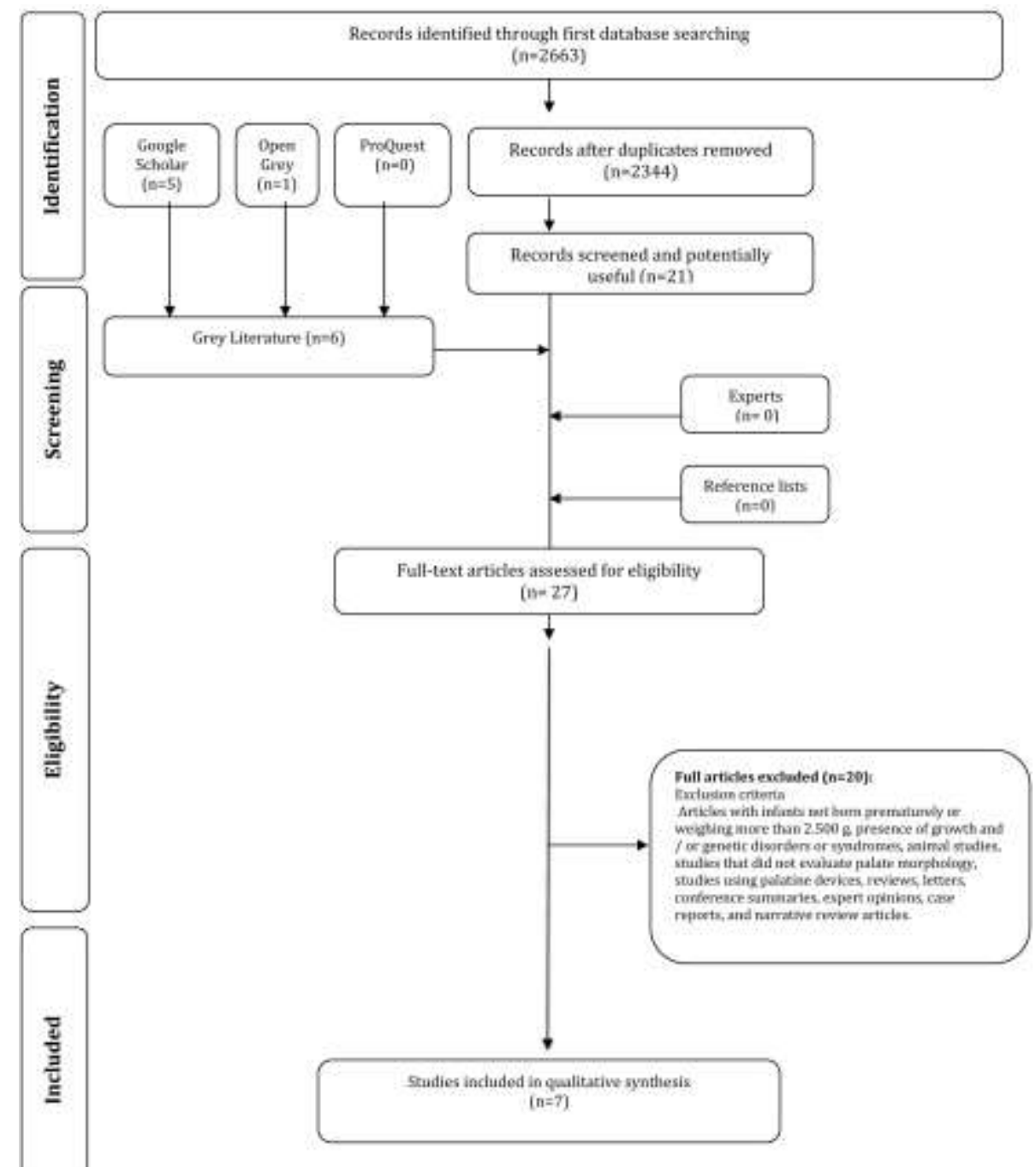

Source: Research Data (2021)

\subsection{Study characteristics}

Of the seven articles selected, two (Alves and Luiz 2012, Germa, Marret et al. 2012) are cohort and five (Kopra and Davis 1991, Procter, Lether et al. 1998, Macey-Dare, Moles et al. 1999, Paulsson, Soderfeldt et al. 2008, Rythen, Thilander et al. 2013), are prospective cross-sectional studies.

Four studies analyzed the change in palate morphology in preterm infants compared to preterm infants. The need for orthodontic correction of malocclusions caused by preterm birth (Paulsson, Soderfeldt et al. 2008) was verified; dento-alveolar changes of adolescents born or not prematurely (Rythen, Thilander et al. 2013), the deformities of the palate in children born prematurely (Procter, Lether et al. 1998) and the alterations of the palate in children born very premature (Germa, Marret et al. 2012).

The remaining three articles (Kopra and Davis 1991, Macey-Dare, Moles et al. 1999, Alves and Luiz 2012), related intubation with the palate morphology. These studies associated intubation with alterations in the palate morphology, alveolar contour, crossbite, eruption sequence, shape and color of the dental crown (Alves and Luiz 2012); intubation with speech characteristics and oral defects (Kopra and Davis 1991); and evaluated palate shape and symmetry related to long-term intubation (Macey-Dare, Moles et al. 1999).

Two articles are from Switzerland (Paulsson, Soderfeldt et al. 2008, Rythen, Thilander et al. 2013), and one from 
Wales (Procter, Lether et al. 1998), England (Macey-Dare, Moles et al. 1999), Brazil (Alves and Luiz 2012), USA (Kopra and Davis 1991) and France (Germa, Marret et al. 2012).

\subsection{Results of studies - Morphology of the palate}

All studies were cross-sectional observational. The majority had a non-premature birth control group (Procter, Lether et al. 1998, Paulsson, Soderfeldt et al. 2008, Germa, Marret et al. 2012, Rythen, Thilander et al. 2013), except for studies comparing intubated and non-intubated children (Kopra and Davis 1991, Macey-Dare, Moles et al. 1999, Alves and Luiz 2012).

Five of the seven studies (Procter, Lether et al. 1998, Paulsson, Soderfeldt et al. 2008, Alves and Luiz 2012, Germa, Marret et al. 2012, Rythen, Thilander et al. 2013), found to be intubation, a risk factor for altered palate morphology (grooves, asymmetries and depth of the palate), while Macey-Dare et al. and Kopra and Davis did not found such correlation (Kopra and Davis 1991, Macey-Dare, Moles et al. 1999).

In the long-term studies, it was observed that altered palatal morphology persisted up to 10 years (Procter, Lether et al. 1998) and 11 years (Macey-Dare, Moles et al. 1999) of age and that intubation was a contributory factor for the palate shape. In the article by Kopra and Davis, evidence was found that intubation significantly increases the prevalence of crossbite in children three to five years of age and of children 7 to 10 years of age (Kopra and Davis 1991).

Summary data concerning the palate morphology of the seven selected studies are listed in Table 1.

Table 1 - Summary of descriptive characteristics of included articles $(n=7)$.

\begin{tabular}{|c|c|c|c|c|c|}
\hline $\begin{array}{l}\text { Author(s), } \\
\text { Year } \\
\text { (Country) }\end{array}$ & Sample & $\begin{array}{l}\text { Age at the } \\
\text { moment of the } \\
\text { evaluation }\end{array}$ & $\begin{array}{l}\text { Evaluation method of } \\
\text { the outcome }\end{array}$ & Results & Conclusions \\
\hline $\begin{array}{c}\text { Procter AM, } \\
\text { Lether D, } \\
\text { Oliver RG, } \\
\text { Cartlidge PH., } \\
1998 \text { (Wales) }\end{array}$ & $\begin{array}{l}76 \text { premature } \\
\text { babies } \\
\text { a) } 27 \text { babies with } \\
\text { less than } 32 \text { weeks } \\
\text { b) } 29 \text { babies } \\
\text { between } 32 \text { and } \\
35 \text { weeks } \\
\text { c) } 20 \text { babies with } \\
36 \text { weeks or more. }\end{array}$ & $\begin{array}{l}25 \text { to } 41 \\
\text { weeks of } \\
\text { gestation } \\
\text { (mean } 33 \\
\text { weeks). }\end{array}$ & $\begin{array}{l}\text { Measurements in the } \\
\text { 5th day of life and, } \\
\text { where possible, } \\
28,32,36,40,53,66,92 \\
\text { weeks post-menstrual } \\
\text { age. } \\
\text { Palatal width and } \\
\text { height measurements } \\
\text { and evaluation based } \\
\text { on the Palatal Index. }\end{array}$ & $\begin{array}{c}\text { Palate depth increased } \\
\text { with a mean of } 6.20 \mathrm{~mm} \\
\text { at week } 28 \text { to } 9.34 \mathrm{~mm} \text { at } \\
\text { week } 53 . \\
\text { Palate width increased } \\
\text { with a mean of } 20.93 \mathrm{~mm} \\
\text { at the 28th week to } 31.20 \\
\text { mm at the } 53 \mathrm{rd} \text { week and } \\
\text { gradually to } 33.80 \mathrm{~mm} \text { at } \\
\text { the } 92 \mathrm{nd} \text { week. }\end{array}$ & $\begin{array}{l}\text { The palatine sulcus is not } \\
\text { caused by the direct pressure } \\
\text { of the orotracheal tube but } \\
\text { by the irritation caused by } \\
\text { the orotracheal tube causing } \\
\text { excessive growth of the } \\
\text { lateral palatine nerves or } \\
\text { because the normal posture } \\
\text { of the tongue at rest against } \\
\text { the arch of the palate may be } \\
\text { limited due to the presence } \\
\text { of orotracheal tube. }\end{array}$ \\
\hline $\begin{array}{c}\text { Alves PV, } \\
\text { Luiz RR., } \\
2012 \text { (Brazil) }\end{array}$ & $\begin{array}{l}117 \text { premature } \\
\text { babies } \\
\text { CASE: } 66 \text { babies } \\
\text { intubated } \\
\text { immediately } \\
\text { after birth. } \\
\text { CONTROL: } 51 \\
\text { babies } \\
\text { who did not need } \\
\text { intubation. }\end{array}$ & $\begin{array}{l}3 \text { to } 5 \text { years and } \\
7 \text { to } 10 \text { years }\end{array}$ & $\begin{array}{l}\text { Intraoral buccal } \\
\text { examination, } \\
\text { intubation } \\
\text { characteristics, } \\
\text { eruption sequence, } \\
\text { anterior crossbite, } \\
\text { upper alveolar contour } \\
\text { and palate shape. }\end{array}$ & $\begin{array}{l}\text { Correlation between } \\
\text { alveolar contour, } \\
\text { crossbite and eruption } \\
\text { sequence. } \\
\text { Correlation between } \\
\text { premature intubated for } \\
\text { long period and changes } \\
\text { in palate shape and } \\
\text { crown shape. }\end{array}$ & $\begin{array}{l}\text { Mechanical trauma caused } \\
\text { by the orotracheal tube } \\
\text { causes oral changes. } \\
\text { The most common } \\
\text { alterations were altered } \\
\text { upper alveolar contour, } \\
\text { followed by anterior } \\
\text { crossbite and palate } \\
\text { deformation. }\end{array}$ \\
\hline
\end{tabular}




\begin{tabular}{|c|c|c|c|c|c|}
\hline $\begin{array}{c}\text { Macey-Dare } \\
\text { LV, } \\
\text { Moles DR, } \\
\text { Evans RD, } \\
\text { Nixon F., } \\
1999 \\
\text { (England) }\end{array}$ & $\begin{array}{c}93 \text { premature } \\
\text { babies } \\
\text { CASE: } 43 \text { infants } \\
\text { with } \\
\text { low weight at } \\
\text { birth. } \\
\text { CONTROL: } 50 \\
\text { babies } \\
\text { not preterm births } \\
\text { and normal weight } \\
\text { at birth. }\end{array}$ & $8-11$ years & $\begin{array}{c}\text { Measurement of arch } \\
\text { and palatine width and } \\
\text { palatine depth, in study } \\
\text { models. } \\
\text { Analysis with } \\
\text { Reflection Microscope, } \\
\text { using fixed rectangular } \\
\text { cartesian coordinate } \\
\text { system and compared } \\
\text { with control group. }\end{array}$ & $\begin{array}{l}\text { Intubated children had } \\
\text { significantly narrower } \\
\text { palatine width in the } \\
\text { posterior region, } \\
\text { significantly steeper } \\
\text { palate in the anterior } \\
\text { region and asymmetry, } \\
\text { the left side being larger } \\
\text { than the right. }\end{array}$ & $\begin{array}{l}\text { Orotracheal tube may exert } \\
\text { excessive force on the } \\
\text { developing alveolus in the } \\
\text { anterior region, causing } \\
\text { greater depth of the palate in } \\
\text { this region and asymmetry } \\
\text { in the width of the palate } \\
\text { that may persist until the age } \\
\text { of } 11 \text { years. }\end{array}$ \\
\hline $\begin{array}{l}\text { Kopra DE, } \\
\text { Davis EL., } \\
1992 \text { (United } \\
\text { States of } \\
\text { America) }\end{array}$ & $\begin{array}{l}\text { CASE: } 40 \text { children } \\
\text { from } 3 \text { to } 5 \text { years } \\
\text { and } 47 \text { from } 7 \text { to } \\
10 \text { years (not } \\
\text { intubated at birth } \\
\text { and not preterm) } \\
\text { CONTROL: } 43 \\
\text { children from } 3 \text { to } \\
5 \text { years and } 47 \\
\text { from } 7 \text { to } 10 \text { years } \\
\text { (intubated and low } \\
\text { weight) }\end{array}$ & $\begin{array}{c}3 \text { to } 5 \text { years and } \\
7 \text { to } 10 \text { years }\end{array}$ & $\begin{array}{l}\text { Surveys of the medical } \\
\text { history of each child, } \\
\text { history of intubation, } \\
\text { videos to analyze } \\
\text { speech, intra-oral } \\
\text { examinations to } \\
\text { analyze the palate, } \\
\text { defects of enamel and } \\
\text { crossbite. } \\
\text { Measurement of } \\
\text { gypsum models with } \\
\text { tridimensional } \\
\text { rectangular cartesian } \\
\text { coordinate system and } \\
\text { aided by the Vidicom } \\
\text { Qualifier } 1210 .\end{array}$ & $\begin{array}{l}\text { The difference between } \\
\text { the medians of the right } \\
\text { and left width was } 0.5 \\
\text { mm for infants who were } \\
\text { intubated and } 0.02 \mathrm{~mm} \\
\text { for nonintubated children } \\
\text { / control group. } \\
\text { Individuals intubated at } \\
\text { both ages had a higher } \\
\text { prevalence of deep } \\
\text { palate, palatine sulcus } \\
\text { and posterior crossbite. }\end{array}$ & $\begin{array}{l}\text { Low weight, intubated } \\
\text { children have a higher } \\
\text { prevalence of oral defects } \\
\text { compared to normal weight } \\
\text { infants who were not } \\
\text { intubated. } \\
\text { Trauma suffered in the oral } \\
\text { cavity occurs due to the } \\
\text { presence of the orotracheal } \\
\text { and / or orogastric tube. }\end{array}$ \\
\hline $\begin{array}{c}\text { Germa A, } \\
\text { Marret S, } \\
\text { Thiriez G, } \\
\text { Rousseau S, } \\
\text { Hascoet JM, } \\
\text { Paulsson- } \\
\text { Bjornsson L et } \\
\text { al., } 2011 \\
\text { (France) }\end{array}$ & $\begin{array}{c}1711 \text { premature } \\
\text { babies } \\
\text { of } 22 \text { and } 32 \\
\text { weeks' gestation } \\
\text { or born between } 22 \\
\text { and } 26 \text { weeks. }\end{array}$ & 5 years & $\begin{array}{c}\text { Evaluation of palatal } \\
\text { morphology evaluated } \\
\text { by visual inspection by } \\
\text { physicians. }\end{array}$ & $\begin{array}{c}\text { The prevalence of altered } \\
\text { palatal morphology was } \\
3.7 \% \text { in the general } \\
\text { sample, } 5.1 \% \text { in boys and } \\
2.2 \% \text { in girls. The risk of } \\
\text { altered palatal } \\
\text { morphology was higher } \\
\text { for the lower gestational } \\
\text { age or infants intubated } \\
\text { for more than } 28 \text { days. }\end{array}$ & $\begin{array}{l}\text { Males, low gestational age } \\
\text { and long-term intubation } \\
\text { were identified as probable } \\
\text { neonatal risk factors for } \\
\text { alteration of palatal } \\
\text { morphology at } 5 \text { years of } \\
\text { age in very premature } \\
\text { children. }\end{array}$ \\
\hline $\begin{array}{c}\text { Rythén M, } \\
\text { Thilander B, } \\
\text { Robertson A., } \\
2012 \\
\text { (Switzerland) }\end{array}$ & $\begin{array}{c}80 \text { extremely } \\
\text { preterm babies } \\
\text { CASE: } 40 \text { with } \\
\text { lower gestational } \\
\text { age } \\
\text { (less than } 29 \\
\text { weeks) } \\
\text { CONTROL: } 40 \\
\text { with } \\
\text { gestational age } \\
\text { period between } 37- \\
43 \text { weeks. }\end{array}$ & $12-16$ years & $\begin{array}{l}\text { Clinical examination, } \\
\text { plaster model } \\
\text { and interproximal } \\
\text { radiographs. } \\
\text { Presence or not of } \\
\text { malocclusions and } \\
\text { altered features of the } \\
\text { palate. } \\
\text { Comparison with } \\
\text { epidemiological } \\
\text { reference material. }\end{array}$ & $\begin{array}{l}\text { There was no difference } \\
\text { between the reference } \\
\text { material } \\
\text { and the control group. } \\
\text { Angle Class II was the } \\
\text { most common } \\
\text { malocclusion associated } \\
\text { with neurological and } \\
\text { neuropsychiatric } \\
\text { morbidity, followed by } \\
\text { crossbite and overjet. }\end{array}$ & $\begin{array}{c}\text { Extremely preterm babies, } \\
\text { in adolescence, has medical } \\
\text { changes, as well as dento- } \\
\text { alveolar alterations when } \\
\text { compared to children born } \\
\text { non-premature. }\end{array}$ \\
\hline $\begin{array}{c}\text { Paulsson L, } \\
\text { Söderfeldt B, } \\
\text { Bondemark L., } \\
2008 \\
\text { (Switzerland) }\end{array}$ & $\begin{array}{l}\text { CASE: } 37 \text { very } \\
\text { preterm babies, } \\
\text { born between } 29- \\
32 \text { weeks and } \\
36 \text { extremily } \\
\text { preterm babies, } \\
\text { born before } 29 \\
\text { weeks } \\
\text { CONTROL: } 41 \text { no } \\
\text { preterm babies. }\end{array}$ & 8 to 10 years & $\begin{array}{l}\text { Clinical examination, } \\
\text { study models and } \\
\text { panoramic radiographs. } \\
\text { Classification by the } \\
\text { Orthodontic Treatment } \\
\text { Needs Index (OTN) }\end{array}$ & $\begin{array}{l}\text { No significant change of } \\
\text { the overjet. Overbite was } \\
\text { the most common } \\
\text { malocclusion in } \\
\text { extremily preterm and } \\
\text { very preterm babies } \\
\text { compared with no } \\
\text { preterm babies. }\end{array}$ & $\begin{array}{l}\text { High rate of malocclusion in } \\
\text { preterm babies compared } \\
\text { with no preterm ones. }\end{array}$ \\
\hline
\end{tabular}

Source: Research Data (2021). 


\subsection{Risk of bias assessment}

The studies selected to answer the question of this review were not homogeneous; most of the studies had a low risk of bias (Kopra and Davis 1991, Procter, Lether et al. 1998, Paulsson, Soderfeldt et al. 2008, Alves and Luiz 2012, Germa, Marret et al. 2012, Rythen, Thilander et al. 2013) and one study had moderate risk (Macey-Dare, Moles et al. 1999).

The risk of bias for each domain assessed by the MASTARI tool are shown in Figure 2, where the color green represents a low risk of bias, yellow represents unclear or lacking in information that would allow judgment, and red a high risk of bias.

Figure 2 Observational studies assessed using the Meta-Analysis of Statistics Assessment and Review Critical Assessment Tools (MASTARI). a) Cross-sectional. Descriptive studies. b) Cohort studies.

A) Cross-sectional. Descriptive Studies.
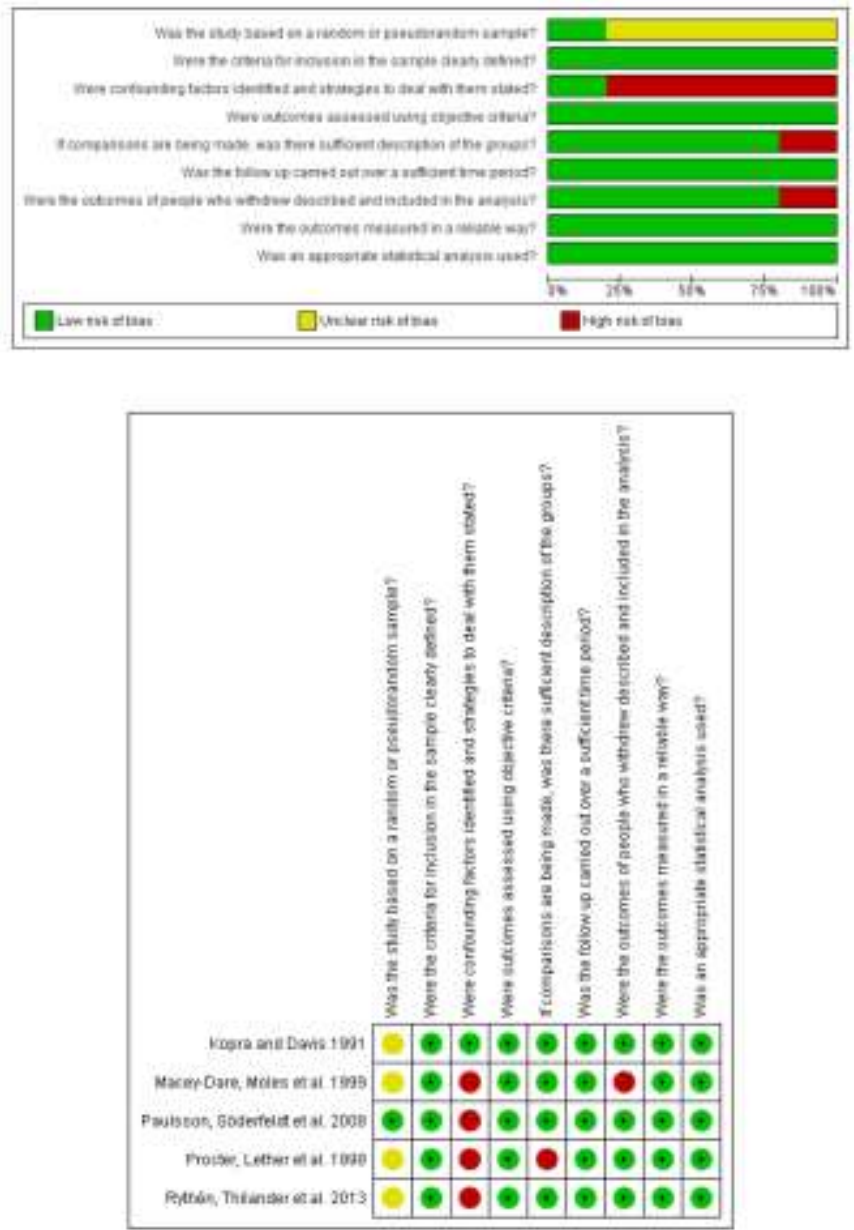

B) Cohort studies
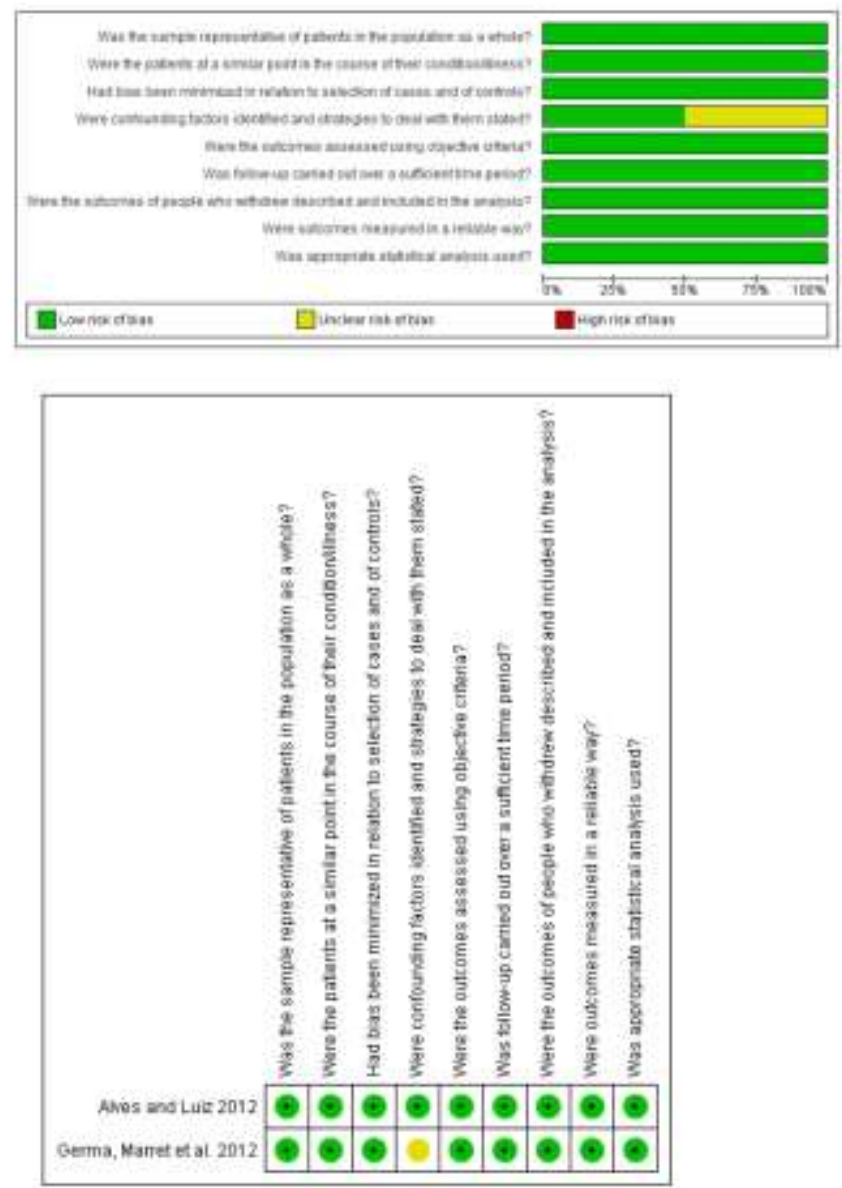

Source: Research Data (2021)

\section{Discussion}

This systematic review was conducted to answer the question: Does preterm birth alter the morphology of the palate? In order to answer this focused question, the bibliographic search was done through the databases, Lilacs, Scopus, Web of Science and PubMed, and it was verified that there is no evidence that preterm delivery alone, alter the morphology of the palate, except when associated to intubation of the newborn.

We selected to be part of this review, articles that used different methods of evaluation, such as visual evaluation based on medical criteria (Germa, Marret et al. 2012), visual evaluation according to pre-established criteria (Alves and Luiz 
2012), gypsum models measured with accuracy up to $0.001 \mathrm{~mm}$ (Kopra and Davis 1991), gauging with digital tweezers (Rythen, Thilander et al. 2013); evaluation of gypsum models under microscope, with fixed rectangular Cartesian coordinate system (Macey-Dare, Moles et al. 1999) and measurement of the palate with microscopic High Precision Electronic Reflection Microscope with resolution of $0.2 \mathrm{~m}$ (Procter, Lether et al. 1998). Although visual evaluations are not considered methods accurate, in the assessment of risk of bias these studies presented low risk.

Advances in technology in neonatal health and intensive care until the 1990s have led to a higher survival rate of very premature and extremely premature children (Copper, Goldenberg et al. 1993), however, preterm birth can still have consequences for the baby's major organs; palate (Kopra and Davis 1991, Macey-Dare, Moles et al. 1999), causing erosion and invagination of the alveolar crest (Ash and Moss 1987), asymmetry of the palate (Saunders, Easa et al. 1976, Carrillo 1985, Paulsson, Soderfeldt et al. 2008), deep palate (Boice, Krous et al. 1976, Saunders, Easa et al. 1976, Moylan, Seldin et al. 1980, Sullivan 1982, Erenberg and Nowak 1984) and narrow (Boice, Krous et al. 1976, Moylan, Seldin et al. 1980, Erenberg and Nowak 1984), dental bite (Paulsson, Soderfeldt et al. 2008), palatine groove (Donley and Nelson 2000) and alteration in the deciduous dentition (Moylan, Seldin et al. 1980, Erenberg and Nowak 1984).

Scientific evidence was found to establish a strong relationship between changes in the morphology of the palate in premature infants, compared with premature infants, and intubation, an important contributing factor. In the comparison between intubated and non-intubated preterm infants, it is observed that mechanical trauma caused by the tube influences oral alterations (Macey-Dare, Moles et al. 1999, Alves and Luiz 2012). Since the palatine bones of the fetuses are spongy and the connective tissue present in the midline forms a fragile palatine configuration, oral defects can easily arise in the presence of orathequeal intubation.

The trauma caused by the tube can also cause the tongue to fail to reach the palate correctly (Kopra and Davis 1991), resulting in significant functional losses (von Gonten, Meyer et al. 1995), such as suctioning problems (Molteni and Bumstead 1986), hearing and middle ear function (Erenberg and Nowak 1984, Molteni and Bumstead 1986). In addition, speech intelligibility or poor speech in contrast to children who do not have oral intubation (Kopra, S. et al. 1988, Kopra and Davis 1991) and hypernasal speech (Boice, Krous et al. 1976, Moylan, Seldin et al. 1980). In more severe cases, the position of the orotracheal tube against the alveolar crest generates an ischemic region, adjacent to the tube , and may cause a crack in this region and once it has occurred, the tube naturally fits into this defect, giving rise to recurrent trauma and eventual necrosis of pressure of the alveolar ridge and underlying dental root (Wetzel 1980). Therefore, these morphological and functional alterations, are not only related to premature birth (Alves and Luiz 2012), as hypothesized at the beginning of the present systematic review, but rather strongly related to orotracheal intubation.

It was verified in the reading of the articles of this review that the length of stay of the orotracheal tube has more influence on the morphology of the palate than the presence of it (Macey-Dare, Moles et al. 1999, Alves and Luiz 2012). Erenberg et al., evaluated 63 newborns who were intubated by 1 to 62 days and stated that the longer the intubation time, the higher the incidence of palatine sulcus, the incidence of $39.5 \%$ in infants intubated for 7 days and $87.5 \%$ in infants intubated for 15 days or more (Erenberg and Nowak 1984). They also reported that the position of the tube and the stage of development of the palate bones are related to the formation of this groove. Likewise, Watterberg and Munsick-Bruno, observed sulcus formation in the palate in $90 \%$ of children who were intubated for 67.6 days on average (Watterberg and Munsick 1986).

Since the palatine sulcus forms due to the continuous pressure of the orotracheal tube against the medial palatine suture (Moylan, Seldin et al. 1980), it is recommended to change the tube from one to the other side to avoid sulcus formation (Duke, Coulson et al. 1976). However, one study revealed that the sulcus occurred even with tubes positioned laterally. The authors attributed this to insufficient tongue pressure against the palatine shelves, allowing the shelves to grow together 
(Carrillo 1985). However, even a tube positioned laterally may exert pressure on the posterior region of the palate, also giving rise to the sulcus (Watterberg and Munsick 1986).

The deleterious effects of orotracheal intubation are observed in the long term (Germa et al., 2012; D. E. Kopra \& Davis, 1991). Watterberg and Munsick-Bruno, observed that $67 \%$ of the children with palatine sulcus due to intubation still presented the sulcus six months after extubation (Watterberg \& Munsick, 1986). The persistence of palatal furrow acquired in the neonatal period was observed for up to five years of age (Adeni, 1989) and the sulcus associated with dental deformities may persist for 2 to 5 years after intubation (Adeni, 1989; Fadavi, Adeni, Dziedzic, Punwani, \& Vidyasagar, 1990; Fadavi S AS, 1989). Warwick-Brown, pointed out that the individual variability of response to the initial trauma should also be considered since it found that the palatine sulcus persisted for up to 21 months in a child intubated for only 8 days and regressed within 24 months in another child intubated for 4 months (Warwick-Brown, 1987).

To minimize the effects of narrowing and deepening of the palate caused by the orotracheal tube, Palatal Stabilizing Devices may be used. Its main function is to distribute the load more evenly over a large area of the palate and to provide additional support for the orotracheal tube (Ash and Moss 1987). In addition, these devices can prevent trauma to the deciduous dentition and better stabilize the tube, avoiding movement of the same and possible accidental extubation (Fadavi, Punwani et al. 1990, von Gonten, Meyer et al. 1995).

There was difficulty in interpreting and comparing the results of the articles used in this review, due to differences in the age range of the participants included and in the moments of evaluation. Some authors evaluated newborns after extubation (Procter, Lether et al. 1998, Alves and Luiz 2012), others collected old data and analyzed at the time of the study, as in the cohort articles that accompanied children from 3 to 5 years and from 7 to 10 years (Kopra and Davis 1991) and 5 years of age (Germa, Marret et al. 2012). Likewise, Macey-Dare et al. studied children from 8 to 11 years old, and Rythén et al., and Paulsson et al., individuals in the 13 and 16 years and from 8 to 10 years respectively, with the aim of evaluating the development of malocclusions (Macey-Dare, Moles et al. 1999, Paulsson, Soderfeldt et al. 2008, Rythen, Thilander et al. 2013).

It is suggested that these different results are also due to the fact that most of the studies, among those selected, disregarded the presence of deleterious habits that these children could have acquired over the years. Kopra and Davis, considered only finger suction and Paulsson et al., referred to "sucking habits" in general (Kopra and Davis 1991, Paulsson, Soderfeldt et al. 2008). Habits are considered important confounding factors, with potential to alter the results of the studies that evaluate oral morphology, because their persistence, plays a significant role in altering the position of the teeth, in the interarc relationship, so as to generate interferences in the normal growth of the jaws and in the function of the orofacial musculature (Farsi and Salama 1997, American Academy of Pediatric Dentistry Council on Clinical Affairs 2005), besides causing changes in the morphology of the palate and crossbite (Larsson 1986). Therefore, they should have been considered in the other five studies selected for the present review.

From the literature review, it was found that preterm birth seems to alter the morphology of the palate, mainly related to the presence of orotracheal intubation, however, there are limitations in the articles published in this regard, possibly due to the difficult management of preterm infants. For this question to be better elucidated, it is suggested to carry out studies, with careful evaluation methodologies, in which the stage of prematurity (premature, very premature and extremely premature) of the included babies and the ages of the individuals studied in the second stage of the study, to be patronized, besides considering the presence and time of orotracheal intubation, the use of devices to protect the palate and deleterious oral habits. 


\section{Conclusion}

Based on this review, it is concluded that preterm birth alters the palate morphology, when prematurity is associated with the use of the orotracheal tube. The knowledge presented in this article can encourage the development of multidisciplinary preventive procedures for the preterm infants, through professionals in the pediatrics, nursing and dentistry areas. Studies with better methodology, with an adequate sampling process and control of possible confounding factors, in addition to better standardization in the way of measuring the outcome, must be carried out, in order to ensure the robustness of the theme.

\section{References}

Adeni, S., Fadavi S., \& Dziedzic. K. (1989). Defects in primary dentition following neonatal intubation. Clin Res, $37,961$.

Alves, P. V., \& Luiz, R. R. (2012). The influence of orotracheal intubation on the oral tissue development in preterm infants. Oral Health Prev Dent, 10(2), 141-7.

American Academy of Pediatric Dentistry Council on Clinical Affairs. (2005). Policy on oral habits. Pediatr Dent, $27(7$ Suppl), 40-1.

Ash, S. P., \& Moss, J. P. (1987). An investigation of the features of the pre-term infant palate and the effect of prolonged orotracheal intubation with and without protective appliances. Br J Orthod, 14(4), 253-61. doi:10.1179/bjo.14.4.253

Avery, F. L. (1988). Determinants of size and maturity at birth. Pediatr Med, 130-45.

Boice, J. B., Krous, H. F., \& Foley, J. M. (1976). Gingival and dental complications of orotracheal intubation. JAMA, 236(8), 957-8.

Carrillo, P. J. (1985). Palatal groove formation and oral endotracheal intubation. Am J Dis Child, 139(9), 859-60. doi:10.1001/archpedi.1985.02140110013008

Copper, R. L., Goldenberg, R. L., Creasy, R. K., DuBard, M. B., Davis, R. O., Entman, S. S., \& Cliver, S. P. (1993). A multicenter study of preterm birth weight and gestational age-specific neonatal mortality. Am J Obstet Gynecol, 168(1 Pt 1), 78-84. doi:10.1016/s0002-9378(12)90889-3

Donley, C. L., \& Nelson, L. P. (2000). Comparison of palatal and alveolar cysts of the newborn in premature and full-term infants. Pediatr Dent, 22(4), 321-4.

Duke, P. M., Coulson, J. D., Santos, J. I., \& Johnson, J. D. (1976). Cleft palate associated with prolonged orotracheal intubation in infancy. J Pediatr, 89(6), 990-1. doi:10.1016/s0022-3476(76)80618-X

Erenberg, A., \& Nowak, A. J. (1984a). Appliance for stabilizing orogastric and orotracheal tubes in infants. Crit Care Med, 12(8), 669-71. doi:10.1097/00003246-198408000-00014

Erenberg, A., \& Nowak, A. J. (1984b). Palatal groove formation in neonates and infants with orotracheal tubes. Am J Dis Child, 138(10), 974-5. doi:10.1001/archpedi.1984.02140480076023

Fadavi, S., Adeni, S., Dziedzic, K., Punwani, I., \& Vidyasagar, D. (1990). Use of a palatal stabilizing device in prevention of palatal grooves in premature infants. Crit Care Med, 18(11), 1279-81. doi:10.1097/00003246-199011000-00019

Fadavi, S., Adeni, S., Dziedzic, K., Punwani, I., \& Vidyasagar, D. (1992). The oral effects of orotracheal intubation in prematurely born preschoolers. ASDC J Dent Child, 59(6), 420-4.

Fadavi, S. Adeni, S., Dziedzic, K., Punwani, I., \& Vidyasagar, D. (1989). The effects of oral intubation on primary dentition- A cross sectional study. J Dent Res, 68, 418 .

Fadavi, S., Punwani, I. C., Vidyasagar, D., \& Adeni, S. (1990). Intraoral prosthetic appliance for the prevention of palatal grooving in premature intubated infants. Clin Prev Dent, 12(1), 9-12.

Farsi, N. M., \& Salama, F. S. (1997). Sucking habits in Saudi children: prevalence, contributing factors and effects on the primary dentition. Pediatr Dent, $19(1), 28-33$.

Germa, A., Marret, S., Thiriez, G., Rousseau, S., Hascoet, J. M., Paulsson-Bjornsson, L., Söderfeldt, B., Ancel, P., Larroque, B., Kaminski, M., \& Nabet, C. (2012). Neonatal factors associated with alteration of palatal morphology in very preterm children: the EPIPAGE cohort study. Early Hum Dev, 88(6), 413-20. doi:10.1016/j.earlhumdev.2011.10.006

Hohoff, A., Rabe, H., Ehmer, U., \& Harms, E. (2005). Palatal development of preterm and low birthweight infants compared to term infants - What do we know? Part 2: The palate of the preterm/low birthweight infant. Head Face Med, 1, 9. doi:10.1186/1746-160X-1-9

Kopra, C. P., Buckwald, S., Kopra, L. F., \& Carter, J. M. (1988). The oral effects of neonatal intubation. J Dent Res, $97,334$.

Kopra, D. E., \& Davis, E. L. (1991). Prevalence of oral defects among neonatally intubated 3- to 5- and 7- to 10-year old children. Pediatr Dent, 13(6), 34955.

Larsson, E. (1986). The effect of dummy-sucking on the occlusion: a review. Eur J Orthod, 8(2), 127-30. doi:10.1093/ejo/8.2.127 
Lissauer T, C. W. (1997). Chapter 9: Perinatal Medicine Illustrated Textbook of Paediatrics.

Macey-Dare, L. V., Moles, D. R., Evans, R. D., \& Nixon, F. (1999). Long-term effect of neonatal endotracheal intubation on palatal form and symmetry in 811-year-old children. Eur J Orthod, 21(6), 703-10. doi:10.1093/ejo/21.6.703

Magalhaes, I. B., Pereira, L. J., Marques, L. S., \& Gameiro, G. H. (2010). The influence of malocclusion on masticatory performance. A systematic review. Angle Orthod, 80(5), 981-7. doi:10.2319/011910-33.1

Marlow, N., Roberts, L., \& Cooke, R. (1993). Outcome at 8 years for children with birth weights of $1250 \mathrm{~g}$ or less. Arch Dis Child, 68(3 Spec No), 286-90. doi:10.1136/adc.68.3_spec_no.286

Moher, D., Liberati, A., Tetzlaff, J., Altman, D. G., \& Group, P. (2009). Preferred reporting items for systematic reviews and meta-analyses: the PRISMA statement. BMJ, 339, b2535. doi:10.1136/bmj.b2535

Molteni, R. A., \& Bumstead, D. H. (1986). Development and severity of palatal grooves in orally intubated newborns. Effect of 'soft' endotracheal tubes. Am J Dis Child, 140(4), 357-9. doi:10.1001/archpedi.1986.02140180091032

Moylan, F. M., Seldin, E. B., Shannon, D. C., \& Todres, I. D. (1980). Defective primary dentition in survivors of neonatal mechanical ventilation. J Pediatr, 96(1), 106-8. doi:10.1016/s0022-3476(80)80341-6

Paulsson, L., Bondemark, L., \& Soderfeldt, B. (2004). A systematic review of the consequences of premature birth on palatal morphology, dental occlusion, tooth-crown dimensions, and tooth maturity and eruption. Angle Orthod, 74(2), 269-9. doi:10.1043/0003-3219(2004)074<0269:ASROTC>2.0.CO;2

Paulsson, L., Soderfeldt, B., \& Bondemark, L. (2008). Malocclusion traits and orthodontic treatment needs in prematurely born children. Angle Orthod, 78(5), 786-92. doi:10.2319/083007-402.1

Procter, A. M., Lether, D., Oliver, R. G., \& Cartlidge, P. H. (1998). Deformation of the palate in preterm infants. Arch Dis Child Fetal Neonatal Ed, 78(1), F29-32. doi:10.1136/fn.78.1.f29

Rythen, M., Thilander, B., \& Robertson, A. (2013). Dento-alveolar characteristics in adolescents born extremely preterm. Eur J Orthod, 35(4), 475-82. doi:10.1093/ejo/cjs034

Saunders, B. S., Easa, D., \& Slaughter, R. J. (1976). Acquired palatal groove in neonates. A report of two cases. J Pediatr, 89(6), 988-989. doi:10.1016/s00223476(76)80617-8

Seow, W. K. (1997). Effects of preterm birth on oral growth and development. Aust Dent J, 42(2), 85-91. doi:10.1111/j.1834-7819.1997.tb00102.x

Stankiewicz, B., Palko, K. J., Darowski, M., Zielinski, K., \& Kozarski, M. (2017). A new infant hybrid respiratory simulator: preliminary evaluation based on clinical data. Med Biol Eng Comput, 55(11), 1937-48. doi:10.1007/s11517-017-1635-9

Stjernqvist, K., \& Svenningsen, N. W. (1999). Ten-year follow-up of children born before 29 gestational weeks: health, cognitive development, behaviour and school achievement. Acta Paediatr, 88(5), 557-62. doi:10.1080/08035259950169594

Sullivan, P. G. (1982). An appliance to support oral intubation in the premature infant. Br Dent J, 152(6), 191-5. doi:10.1038/sj.bdj.4804784

von Gonten, A. S., Meyer, J. B., Jr., \& Kim, A. K. (1995). Dental management of neonates requiring prolonged oral intubation. J Prosthodont, 4(4), 221-5. doi:10.1111/j.1532-849x.1995.tb00345.x

Warwick-Brown, M. M. (1987). Neonatal palatal deformity following oral intubation. Br Dent J, 162(7), 258-9. doi:10.1038/sj.bdj.4806097

Watterberg, K. L., \& Munsick, B. (1986). Incidence and persistence of acquired palatal groove in preterm neonates following prolongued orotracheal intubation. Pediatr Res, 20, 1357.

Wetzel, R. C. (1980). Defective dentition following mechanical ventilation. J Pediatr, 97(2), 334. doi:10.1016/s0022-3476(80)80519-1

Wolke, D. (1998). Psychological development of prematurely born children. Arch Dis Child, 78(6), 567-70. doi:10.1136/adc.78.6.567

World Health Organization. (2015). Brazil: WHO statistical profile. Retrieved from https://www.who.int/gho/countries/bra.pdf 